\title{
PENGGUNAAN KOMBINASI FOTOKATALIS TiO 2 DAN ARANG AKTIF UNTUK PENGOLAHAN LIMBAH FARMASI
}

\author{
Sofia Fatmawati ${ }^{1}$, F.X Sulistiyanto W. S $^{1}$, Uning Rininingsih E. $\mathbf{M}^{1}$ \\ ${ }^{1}$ Sekolah Tinggi Ilmu Farmasi "Yayasan Pharmasi Semarang" \\ "Email: fatmawatisofia@gmail.com
}

\begin{abstract}
Abstrak
Air limbah farmasi memiliki dampak yang berbahaya bagi lingkungan. Air limbah tersebut dicemari oleh zat kimia organik dan anorganik. Limbah antibiotik seperti misalnya siprofloksasin dapat bersama-sama dengan limbah anorganik seperti ion Cu(II) di perairan. Metode fotokatalisis menggunakan TiO2 telah terbukti berpotensi untuk mengatasi pencemaran limbah dengan cara yang ramah lingkungan serta menghemat biaya. Arang aktif merupakan media adsorpsi yang tepat untuk disisipkan katalis TiO2 karena dapat menangkap dan menjerap partikel-partikel sangat halus, tidak bersifat racun, mudah didapat , ekonomis dan dapat meningkatkan aktivitas fotokatalitik dari TiO2 dengan memperluas permukaan serta mencegah penggumpalan partikel dari TiO2. Penelitian ini bertujuan untuk mengetahui pengaruh keberadaan arang aktif dan lama penyinaran terhadap efektivitas proses fotodegradasi siprofloksasin yang terkatalisis TiO2 dengan keberadaan ion Cu(II). Metode penelitian dilakukan dalam suatu reaktor tertutup yang dilengkapi dengan satu sdkkat pengaduk magnetik dan lampu tungsten sebagai sumber sinar tampak. Variasi lama penyinaran yang digunakan adalah 20, 40, 60, 80 dan 100 menit. Sedangkan massa kombinasi TiO2 dengan Arang aktif yang digunakan adalah $25: 1,30: 1$, dan $35: 1$. Metode yang digunakan untuk mengetahui konsentrasi siprofloksasin adalah Spektrofotometri Ultra Violet dan konsentrasi ion Cu(II) menggunakan Spektrofotometri Serapan Atom. Hasil penelitian menunjukan adanya pengaruh variasi lama penyinaran dan variasi massa TiO2 dan arang aktif pada fotodegradasi siprofloksasin dan fotoreduksi ion Cu(II). Kondisi optimal lama penyinaran pada proses fotodegradasi siprofloksasin dan fotoreduksi ion $\mathrm{Cu}(\mathrm{II})$ adalah 100 menit dan dengan variasi TiO2 kombinasi Arang Aktif adalah 35 : 1, pada kondisi tersebut siprofloksasin yang terdegradasi $82,18 \%$ dan ion Cu(II) yang tereduksi 89,83\%.
\end{abstract}

\section{Kata kunci: Arang aktif; fotokatalis TiO2; ion Cu; siprofloksasin}

\section{PENDAHULUAN}

Limbah industri farmasi berkaitan erat dengan masalah pencemaran lingkungan khususnya pencemaran air. Beberapa jenis senyawa obat yang merupakan limbah industri farmasi seperti antibiotik, hormon, pengawet, dan anestesi apabila dibuang tanpa proses pengolahan terlebih dahulu mengakibatkan limbah industri farmasi akan bermuara ke laut sehingga air laut menjadi tercemar (Bila dkk., 2003).

Air juga sering tercemar oleh komponenkomponen anorganik seperti logam berat yang berbahaya, salah satunya adalah ion $\mathrm{Cu}(\mathrm{II})$. Keberadaan ion $\mathrm{Cu}$ (II) dalam lingkungan dapat berasal dari pembuangan air limbah industri yang berasal dari industri electroplating, keramik, dan fotografi. Apabila logam tersebut terakumulasi di dalam tubuh dalam jangka waktu lama dan dalam jumlah banyak dapat menyebabkan toksisitas akut dan bersifat fatal (Fardiaz, 1992).
Keberadaan senyawa farmasi dan logam berat dalam air mengakibatkan pencemaran yang dapat mencemari biota, sehingga berdampak pada manusia yang gemar mengonsumsi hasil perikanan. Untuk menghindari dampak negatif tersebut maka keberadaan senyawa farmasi dan logam berat perlu dihilangkan dari perairan.

Dalam beberapa tahun terakhir, metode fotokatalisis menggunakan $\mathrm{TiO} 2$ telah berpotensi untuk mengatasi pencemaran limbah dengan cara yang ramah lingkungan serta menghemat biaya (Behpour dkk., 2010). Pada awal perkembangannya, $\mathrm{TiO} 2$ digunakan sebagai fotokatalis mempunyai kelemahan dalam hal pemisahan katalis setelah proses degradasi dan daya adsorpsi katalis terhadap limbah. TiO2 sering digunakan untuk fotoreduksi ion logam dan fotooksidasi atau fotodegradasi senyawa organik karena murah dan penanganannya mudah. Fotokatalis $\mathrm{TiO} 2$ dapat mereduksi ion $\mathrm{Cu}$ (II) menjadi bentuk logam $\mathrm{Cu}$ sehingga tidak toksik di lingkungan 
karena TiO2 mempunyai struktur semikonduktor yang dapat menyediakan elektron setelah disinari dengan energi yang sesuai. TiO2 adalah fotokatalis paling cocok untuk mengatasi pencemaran air limbah karena bersifat inert secara kimia maupun biologi, biaya relatif murah, dan tidak toksis (Behpour, dkk., 2010). Fotokatalis jika disinari dengan panjang gelombang antara 100-400 nm elektron akan teraktivasi dari pita valensi menuju pita konduksi sehingga menyebabkan terbentuknya hole (muatan positif) pada pita valensi berinteraksi dengan $\mathrm{H} 2 \mathrm{O}$ membentuk radikal $\mathrm{OH}$ yang bersifat sebagai oksidator kuat sehingga akan mendegradasi senyawa organik dan elektron pada pita konduksi (muatan negatif) yang berguna untuk mereduksi senyawa anorganik (Perdana dkk., 2014). Mengingat fotoreduksi merupakan pasangan fotodegradasi maka penelitian ini mempelajari efektivitas fotodegradasi siprofloksasin yang terkatalisis $\mathrm{TiO} 2$ dengan keberadaan ion $\mathrm{Cu}$ (II).

Berdasarkan penelitian yang dilakukan oleh Basuki pada tahun 2008, arang aktif adalah media adsorpsi yang dapat disisipkan pada katalis $\mathrm{TiO} 2$ karena dapat menangkap dan mengadsorpsi partikelpartikel sangat halus serta bersifat non-toksik, mudah dibuat dan didapatkan juga ekonomis. Arang aktif dapat meningkatkan aktivitas fotokatalitik dari $\mathrm{TiO} 2$ dengan memperluas permukaan dari TiO2. Dari hasil karakterisasi dengan Scanning Electron Microscopy, arang aktif dapat mencegah penggumpalan antara partikel-partikel $\mathrm{TiO} 2$. Andayani (2006) telah meneliti kombinasi katalis TiO2-arang aktif yang disintesa dengan proses sol-gel dan diimobilisasi pada pelat titanium, katalis dibuat dengan berbagai rasio TiO2-arang aktif dan terbukti arang aktif dapat meningkatkan aktivitas katalitik dari TiO2. Penelitian ini bertujuan untuk menggunakan kombinasi fotokatalis $\mathrm{TiO} 2$ dan arang aktif yang dapat mendegradasi siprofloksasin sehingga tidak toksik di lingkungan karena $\mathrm{TiO} 2$ mempunyai struktur semikonduktor (Septiani dkk., 2015).

\section{METODOLOGI}

Bahan yang digunakan dalam penelitian ini adalah TiO2 (Multi Kimia Raya Chemicals), siprofloksasin (Brataco), CuSO4.5H2O (Merck), arang aktif, $\mathrm{NaOH}$ (Merck), H2SO4
(Merck), akuades, dan kertas saring Whatman 42 (D: $110 \mathrm{~mm}$ ). Peralatan yang digunakan dalam penelitian ini meliputi reaktor yang dilengkapi dengan satu sdkkat pengaduk magnetik merk Spinbar ukuran $2 \mathrm{~cm}$ dan lampu UV C 20 watt tipe black light blue (BLB) merk philips. Alat gelas laboratorium dan instrumen meliputi erlenmeyer, pipet volume, corong gelas, labu ukur, gelas beker, neraca analitik, spektrofotometer serapan atom merk Perkin Elmer no seri 3110, dan spektrofotometer UV mini-1240 merk Shimadzu.

Preparasi katalis dilakukan dengan cara mencampurkan 4 gram TiO2, $200 \mathrm{ml}$ aquadest dan disonikasi selama 20 menit setelah itu dipanaskan menggunakan hot plate untuk menguapkan kandungan air yang masih tersisa sehingga akan berbentuk pasta. Pasta tersebut dikeringkan di dalam oven pada temperature $100{ }^{\circ} \mathrm{C}$ selama 2 jam dan dikalsinasi pada temperature $500{ }^{\circ} \mathrm{C}$ di dalam furnace selama 5 jam, kemudian didinginkan. $\mathrm{TiO} 2$ dan arang aktif disuspensikan dalam aquademin, selanjutnya suspensi diletakkan dalam sonikator selama 5 jam, setelah disaring kemudian dikeringkan dalam oven dengan suhu $105^{\circ} \mathrm{C}$ selama 24 jam.

Proses fotodegradasi yang terkatalisis $\mathrm{TiO} 2$ dilakukan dengan sistem batch dalam reaktor tertutup yang dilengkapi dengan lampu tungsten dan plat pengaduk magnetik. Proses fotodegradasi dilakukan dengan cara menyinari campuran yang terdiri dari larutan siprofloksasin dengan konsentrasi $50 \mathrm{mg} / \mathrm{L}$ sebanyak $25 \mathrm{ml}$, kemudian ditambah dengan larutan ion logam $\mathrm{Cu}$ (II) $100 \mathrm{mg} / \mathrm{mL}$ sebanyak $25 \mathrm{~mL}$, dan ditambahkan fotokatalis $\mathrm{TiO} 250$ mg sehingga diperoleh suspensi. Selanjutnya melakukan variasi perbandingan larutan sampel dan arang aktif yaitu 25:1, 30:1, dan 35:1. Erlenmeyer ditutup dengan plastik transparan kemudian disinari dengan lampu tungstein disertai pengadukan selama 20, 40,60, 80 dan 100 menit. Untuk memperoleh filtrat dari suspensi tersebut dilakukan penyaringan dengan kertas whatman. Selanjutnya filtrat dianalisis dengan alat spektrofotometer UV untuk menentukan konsentrasi siprofloksasin yang tidak terdegradasi dan alat Spektrofotometer Serapan Atom (SSA) untuk menentukan konsentrasi ion logam $\mathrm{Cu}$ (II) yang tidak tereduksi. Berdasarkan data absorbansi yang diperoleh, konsentrasi siprofloksasin dan ion $\mathrm{Cu}(\mathrm{II})$ sisa dihitung dengan memasukkan data absorbansi pada kurva standar. 


\section{HASIL DAN PEMBAHASAN}

Penelitian ini bertujuan untuk mengetahui pengaruh lama penyinaran dan kombinasi senyawa arang aktif terhadap efektivitas fotodegradasi siprofloksasin dan fotoreduksi ion $\mathrm{Cu}$ (II) menggunakan fotokatalis $\mathrm{TiO} 2$. Proses fotodegradasi siprofloksasin dan fotoreduksi ion logam $\mathrm{Cu}$ (II) dilakukan dengan cara menyinari campuran yang terdiri dari larutan siprofloksasin, larutan ion logam $\mathrm{Cu}$ (II), serta serbuk fotokatalis $\mathrm{TiO} 2$ menggunakan sinar lampu UV disertai dengan pengadukan menggunakan pengaduk magnet didalam sebuah reaktor tertutup. Lampu UV ini berfungsi sebagai sumber energi foton yang akan mengaktivasi $\mathrm{TiO} 2$ sehingga reaksi fotokatalis dapat berlangsung, sedangkan pengaduk magnet digunakan untuk mencampurkan semua reaktan secara merata sehingga proses fotodegradasi siprofloksasin dan fotoreduksi ion logam $\mathrm{Cu}$ (II) berlangsung efektif.

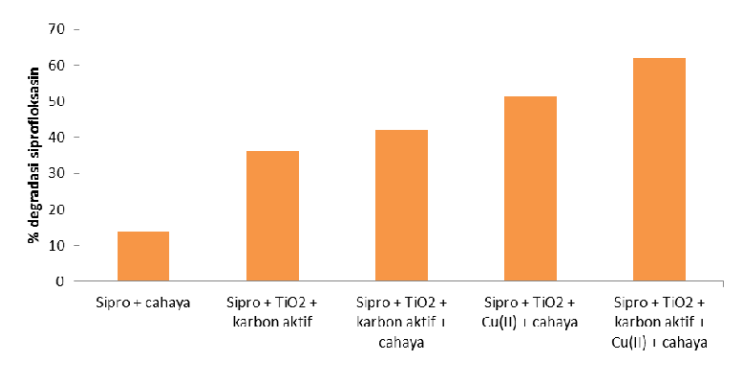

\section{Gambar 1. Grafik orientasi penyinaran lampu tungstein, fotokatalis $\mathrm{TiO} 2$ dan keberadaan ion logam $\mathrm{Cu}$ (II) terhadap fotodegradasi siprofloksasin}

Untuk mendukung data eksperimen, terlebih dahulu dilakukan proses orientasi fotodegradasi untuk mengetahui pengaruh sinar tampak, pengaruh fotokatalis, maupun adanya ion logam $\mathrm{Cu}$ (II) terhadap efektivitas degradasi siprofloksasin dengan berbagai kondisi (gambar 1). Hasil orientasi memperlihatkan bahwa penyinaran dengan dan tanpa penambahan fotokatalis $\mathrm{TiO} 2$ dapat menurunkan konsentrasi siprofloksasin. Penurunan konsentrasi siprofloksasin juga terjadi pada campuran larutan siprofloksasin dan fotokatalis $\mathrm{TiO} 2$ yang direaksikan di tempat gelap (tanpa penyinaran). Penurunan konsentrasi siprofloksasin yang disinari tanpa adanya fotokatalis $\mathrm{TiO} 2$ terjadi karena adanya reaksi antara siprofloksasin dengan radikal $\bullet \mathrm{OH}$ yang dihasilkan dari peruraian molekul $\mathrm{H} 2 \mathrm{O}$ setelah menyerap sinar lampu UV atau energi foton (hv). Reaksi penyerapan cahaya oleh $\mathrm{H} 2 \mathrm{O}$ selain menghasilkan elektron juga menghasilkan radikal $\bullet \mathrm{OH}$ dan $\mathrm{H}+$ yang disebut reaksi fotolisis (Burrows, dkk, 1998). Reaksi fotolisis molekul air dapat dituliskan sebagai berikut:

$$
\begin{array}{lll}
\mathrm{H} 2 \mathrm{O}+\mathrm{hv} \rightarrow & \bullet \mathrm{OH}+\mathrm{H}++\mathrm{e}- & (1) \\
\text { Adanya penurunan } & \text { konsentrasi }
\end{array}
$$
siprofloksasin yang cukup besar pada penambahan fotokatalis $\mathrm{TiO} 2$ dengan penyinaran dapat terjadi karena saat $\mathrm{TiO} 2$ terpapar sinar lampu UV maka akan memproduksi elektron dan radikal $\bullet \mathrm{OH}$ dalam jumlah yang cukup besar yang dapat mendukung proses fotodegradasi siprofloksasin menjadi lebih efektif (Hoffmann dkk., 1995). Keberadaan ion logam $\mathrm{Cu}(\mathrm{II})$ juga dimungkinkan dapat memberikan pengaruh terhadap peningkatan fotodegradasi yang dikatalisis TiO-arang aktif karena merupakan senyawa anorganik yang bisa mengalami proses fotoreduksi. Ion logam $\mathrm{Cu}(\mathrm{II})$ akan berikatan dengan elektron (mengalami reduksi) pada permukaan $\mathrm{TiO} 2$ sehingga dapat mencegah terjadinya penggabungan kembali antara elektron dengan radikal $\bullet \mathrm{OH}$.

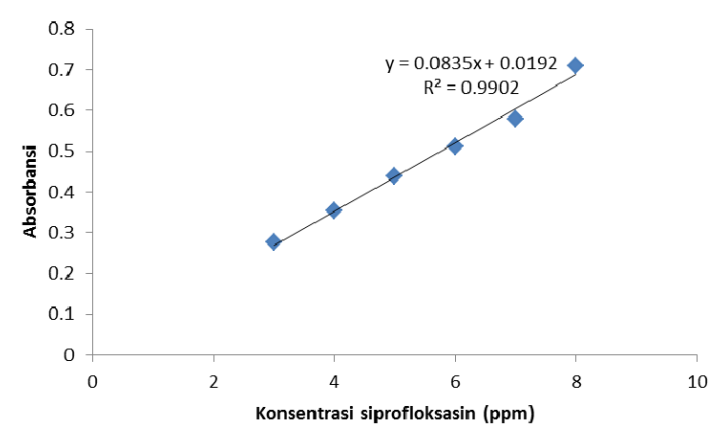

\section{Gambar 2. Kurva kalibrasi standart siprofloksasin}

Penentuan sisa siprofloksasin yang tidak terdegradasi dilakukan dengan metode Spektrofotometri UV karena mempunyai gugus kromofor dan auksokrom pada panjang gelombang maksimal agar memberikan serapan yang maksimal. Dari hasil scanning didapatkan bahwa serapan siprofloksasin yang maksimal pada panjang gelombang 272,90 $\mathrm{nm}$ (Moffat dkk., 2005). Konsentrasi sampel siprofloksasin yang diukur dan ditetapkan dengan mengintrapolasikan hasil absorbansi sampel pada kurva kalibrasi standart siprofloksasin 
(gambar 2). Hasil fotodegradasi dinyatakan dalam persen (\%) siprofloksasin terdegradasi yang dihitung berdasarkan selisih massa siprofloksasin mula-mula dengan siprofloksasin sisa. Hasil fotoreduksi dinyatakan dalam persen (\%) $\mathrm{Cu}(\mathrm{II})$ tereduksi yang dihitung berdasarkan selisih massa $\mathrm{Cu}(\mathrm{II})$ mula-mula dengan $\mathrm{Cu}(\mathrm{II})$ sisa yang diukur menggunakan spektrofotometer serapan atom (SSA).

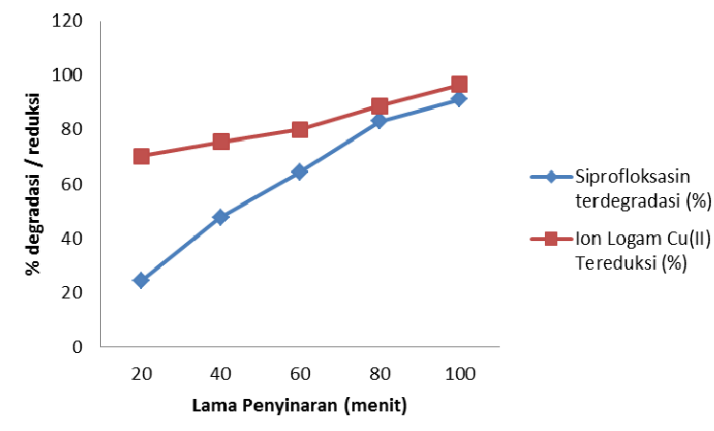

\section{Gambar 3. Pengaruh lama penyinaran katalis $\mathrm{TiO} 2$ terhadap fotodegradasi siprofloksasin dan fotoreduksi ion logam $\mathrm{Cu}(\mathrm{II})$}

Pada gambar 3 terlihat bahwa semakin lama waktu penyinaran disertai dengan meningkatnya proses fotodegradasi siprofloksasin. Semakin lamanya penyinaran maka sinar foton yang meradiasi $\mathrm{TiO} 2$ semakin banyak, sehingga hole yang bereaksi dengan $\mathrm{H} 2 \mathrm{O}$ untuk membentuk radikal $\bullet \mathrm{OH}$ juga semakin banyak (Darmawan, 2013). Radikal -OH yang terbentuk bereaksi dengan siprofloksasin sehingga konsentrasinya dalam larutan akan semakin menurun. Fotodegradasi oleh $\mathrm{TiO} 2$ juga telah diuji untuk beberapa senyawa organick seperti zat warna methyl orange (Darmawan, 2013), remazol yellow (Poluakan, 2015) dan amoksisilin (Wildan, 2016). Seperti halnya siprofloksasin, semakin lama penyinaran maka semakin lama juga kontak antara fotokatalis $\mathrm{TiO} 2$ dengan energi foton dari sinar lampu. Elektron yang tersedia di permukaan fotokatalis $\mathrm{TiO} 2$ akan semakin berlimpah dan bereaksi dengan ion $\mathrm{Cu}$ (II). Jika banyak ion $\mathrm{Cu}$ (II) yang bereaksi dengan elektron maka dapat dipastikan bahwa penurunan konsentrasi ion $\mathrm{Cu}$ (II) dalam larutan semakin meningkat.

Penambahan arang aktif berpengaruh terhadap fotokatalis $\mathrm{TiO} 2$ dalam mendegradasi siprofloksasin (gambar 4). Hal ini dapat dilihat dari hasil perbandingan massa katalis tersebut, semakin besar rasio arang aktif terhadap TiO2 maka persen siprofloksasin yang terdegradasi semakin menurun. Peningkatan aktivitas TiO2 dengan penambahan arang aktif terjadi karena arang aktif berfungsi sebagai adsorben sehingga siprofloksasin dan ion logam $\mathrm{Cu}$ (II) akan terkonsentrasi pada arang aktif sehingga proses fotokatalisis oleh $\mathrm{TiO} 2$ akan semakin efisien karena semakin banyak siprofloksasin dan ion $\operatorname{logam} \mathrm{Cu}$ (II) yang berhubungan dengan $\mathrm{TiO} 2$.

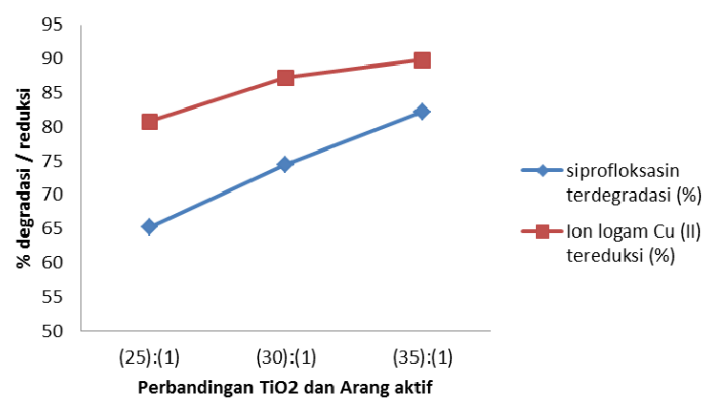

\section{Gambar 4. Pengaruh variasi massa $\mathrm{TiO} 2$ kombinasi arang aktif terhadap fotodegradasi siprofloksasin dan fotoreduksi ion logam $\mathrm{Cu}(\mathrm{II})$}

Penurunan aktivitas fotokatalis pada penambahan arang aktif lebih lanjut terjadi karena permukaan fotokatalis yang tidak merata dan pori-pori yang semakin mengecil, sehingga jumlah siprofloksasin dan ion logam yang teradsorpsi oleh fotokatalis semakin menurun yang akan menurukan aktivitas fotokatalis (Riyani, 2008). Sejumlah kecil siprofloksasin dan ion logam $\mathrm{Cu}$ (II) yang berkurang kemungkinan teradsorpsi oleh material adsorben arang aktif dan sebagian besarnya terdegradasi oleh fotokatalis $\mathrm{TiO} 2$ dan sinar UV (Poluakan dkk., 2015).

\section{KESIMPULAN}

Hasil penelitian menunjukan adanya pengaruh variasi lama penyinaran dan variasi massa $\mathrm{TiO} 2$ dan arang aktif pada fotodegradasi siprofloksasin dan fotoreduksi ion logam $\mathrm{Cu}(\mathrm{II})$. Kondisi optimal lama penyinaran pada proses fotodegradasi siprofloksasin dan fotoreduksi ion logam $\mathrm{Cu}$ (II) adalah 100 menit dan dengan variasi $\mathrm{TiO} 2$ kombinasi Arang Aktif adalah 35 : 1, pada kondisi tersebut siprofloksasin yang terdegradasi $82,18 \%$ dan ion logam $\mathrm{Cu}(\mathrm{II})$ yang tereduksi $89,83 \%$. 


\section{UCAPAN TERIMA KASIH}

Terima kasih kepada Kemenristek Dikti untuk pendanaan Penelitian Dosen Pemula (PDP) tahun pelaksanaan 2017.

\section{DAFTAR PUSTAKA}

Andayani, W. dan Agustin, S. (2006). Karakterisasi Katalis $\mathrm{TiO}_{2}$ dan $\mathrm{TiO}_{2} /$ Karbon aktif yang diimobilisasi pada pelat titanium dan uji aktifitasnya sebagai fotokatalis, Jurnal Kimia Indonesia. 1(2): 54-58.

Basuki, K. T., Setiawan, B., Nurimaniwathy. (2008). Penurunan Konsentrasi Co Dan $\mathrm{NO}_{2}$ Pada Emisi Gas Buang Menggunakan Arang Tempurung Kelapa Yang Disisipi $\mathrm{TiO}_{2}$. Seminar Nasional IV SDM Teknologi Nuklir, Yogyakarta.

Behpour, M., Ghoreishi, S. M., dan Razavi, F. S. (2010). Photocatalytic Activity of $\mathrm{TiO}_{2} /$ Ag Nanoparticle on Degradation of Water Pollutions. Digest Journal of Nanomaterials and Biostructures. 5. (2) : 467-475.

Bila, D. dan Denzotti, M. (2003). Pharmeceutical Drugs In The Environment. Quimica Nova. 26 : 523530.

Burrows, H, D., Ernestova, L. S., Kemp, T. J., Skurlatov, Y., I., Purmal, A. P., \& Yermakov, A. N. 1998. Kinetics and mechanism of photodegradation of chlorophenol. J. Sci. \& Techn. Lett. 23, 4285-4299.

Darmawan, P. R., Wardani, S., Purwonugroho, D. (2013). Pengaruh Penambahan No3Terhadap Degradasi Methyl Orange Menggunakan Fotokatalis $\quad \mathrm{TiO}_{2}{ }^{-}$ Bentonit. Kimia Student Journal. 1. (1): 140-146

Fardiaz, S. (1992). Polusi air \& udara. Penerbit Kanisius. Yogyakarta.

Hoffmann, M. R., Martin, S. T., Choi, W., dan Bahnemann, D. W. (1995). Environmental Applications of Semiconductor Photocatalysis. Chem. Rev. 95 : 69-96.

Moffat, A.C. (2005). Clarke's Analysis Of Drug And Poisons Thirth edition. London: Pharmaceutical Press, Electronic version.
Perdana, D. N., Wardhani, S., Khunur, M. (2014). Pengaruh Penambahan Hidrogen Peroksida $\left(\mathrm{H}_{2} \mathrm{O}_{2}\right)$ Terhadap Degradasi Methylene Blue Dengan Menggunakan Fotokatalis ZnO-Zeolit. Kimia Student Journal. 2 : 576-582.

Poluakan, M., Wuntu, A., Sangi, M. S. (2015). Aktivitas Fotokatalitik TiO2-Karbon Aktif dan TiO2-Zeolit pada Fotodegradasi Zat Warna Remazol Yellow. Jurnal Mipa Unsrat Online. 4 (2): 137-140.

Riyani, K., Setyaningtyas, T., Andreas., R. (2008). Pengolahan Limbah Logam Berat Industri Tekstil Menggunakan Fotokatalis TiO2/Arang Aktif. Molekul. 3.( 1) : 40 - 47

Septiani, U., Gustiana, M., Safni. (2015). Pembuatan Dan Karakterisasi Katalis TiO2/Karbon Aktif Dengan Metode Solid State. J. Ris. Kim. 9. (1) : 34-38.

Wildan, A., Mutiara, E.V. (2016). Pengolahan Limbah Organik Dan Anorganik Menggunakan Fotokatalis $\mathrm{TiO}_{2}$ DopanN. Inovasi Teknik Kimia, 1(1) : 09-16. 